\title{
White Matter Lesions and Brain Atrophy: More than Shared Risk Factors? A Systematic Review
}

\author{
Auke P.A. Appelman ${ }^{a, b}$ Lieza G. Exalto ${ }^{c}$ Yolanda van der Graaf ${ }^{b}$ \\ Geert Jan Biessels ${ }^{c}$ Willem P.T.M. Mali ${ }^{a}$ Mirjam I. Geerlings ${ }^{b}$ \\ ${ }^{a}$ Department of Radiology, ${ }^{b}$ Julius Center for Health Sciences and Primary Care, and ${ }^{\mathrm{C}}$ Rudolf Magnus Institute of \\ Neurosciences, Department of Neurology, Department of Neurology, University Medical Center Utrecht, Utrecht, \\ The Netherlands
}

\section{Key Words}

Lacunar infarcts $\cdot$ White matter hyperintensities $\cdot$ Brain atrophy $\cdot$ Magnetic resonance imaging $\cdot$ Systematic reviews $\cdot$ Vascular risk factors

\begin{abstract}
Background: White matter lesions (WML) and brain atrophy are often found on MRI in the elderly. Shared vascular risk factors may be an explanation for their concomitance. However, disturbances of white matter integrity could also be involved in the pathogenesis of brain atrophy. Our objective was to systematically review studies that investigated the relation between WML and brain atrophy on MRI, and to investigate whether there is sufficient evidence to indicate that this relation is independent of shared risk factors. Methods: We searched PubMed for studies published in English between 1980 and October 2007, combining search terms for WML and brain atrophy. Articles that studied the relation between WML and brain atrophy were included if they met the following criteria: (1) original study, (2) MRI used for imaging, (3) assessment methods for WML and brain atrophy specified, and (4) a sample size of at least 20 participants. We recorded type and age of the study population, type and assessment of WML and brain atrophy, and variables for which
\end{abstract}

adjustments were made in the analyses. Results: We identified 48 studies that met our inclusion criteria. A significant relation between WML and brain atrophy was found in 37 out of 48 studies. The source of the study population (e.g. clinic or population based) did not affect this relation. However, only 10 studies adjusted for shared risk factors, of which 9 found an association. Conclusions: The majority of studies found an association between WML and brain atrophy, but it is not yet clear if this association is independent of shared risk factors.

Copyright $\odot 2009$ S. Karger AG, Basel

\section{Introduction}

In healthy individuals, global and regional brain volume decline starts at a slow rate in early adulthood and accelerates in older age [1-3]. The rate of this decline varies considerably among individuals [3]. This is of clinical importance since the extent and rate of progression of global and regional brain atrophy are associated with future cognitive deterioration and conversion to dementia [4-6].

Although brain atrophy may be caused by specific neurological diseases, it is often found on MRI in the el-

\section{KARGER}

Fax +4161306 1234 E-Mail karger@karger.ch www.karger.com (c) 2009 S. Karger AG, Basel

$1015-9770 / 09 / 0283-0227 \$ 26.00 / 0$

Accessible online at:

www.karger.com/ced
Mirjam Geerlings

University Medical Center Utrecht, Julius Center for Health Sciences and

Primary Care, Stratenum 6.131, PO Box 85500

NL-3508 GA Utrecht (The Netherlands)

Tel. +31 8875593 94, Fax +31 8875554 85, E-Mail m.geerlings@umcutrecht.nl 
derly without apparent neurological symptoms. Evidence has accumulated that vascular factors play an important role in the etiology of brain atrophy and development of dementia. These factors include hypertension $[7,8]$, hyperlipidemia [8], diabetes mellitus [9], obesity [10], large amounts of alcohol [11], and cigarette smoking $[8,9]$.

In addition to brain atrophy, the presence and severity of white matter lesions (WML) increase with age [12-14]. They too are associated with future cognitive decline and dementia [15-18]. Patients with subcortical vascular ischemic disease, which is characterized by substantial WML, show progressive cognitive impairment in specific domains and have a considerable risk of developing dementia $[19,20]$. Furthermore, vascular risk factors, including hypertension [12, 14, 21-25], diabetes mellitus [26], obesity $[27,28]$, and smoking $[14,23]$, are also associated with WML.

More than 100 years ago, Alois Alzheimer and Otto Binswanger had already described the concomitant presence of subcortical vascular pathology and pronounced atrophy of the white matter with enormously enlarged ventricles in postmortem studies [29]. More recently, concomitant brain atrophy and WML have frequently been observed in elderly people on magnetic resonance imaging (MRI). However, it is unknown which factors may explain the co-occurrence of WML and brain atrophy. One possibility is that their coexistence may be explained by shared vascular risk factors or other shared factors associated with aging. Another possibility is that the disturbances of white matter integrity can contribute to the pathogenesis of brain atrophy by causing ischemic damage to axons, oligodendrocytes, and other glial cells [30].

In this study, we systematically reviewed available studies that investigated the relation between WML and global or regional brain atrophy on MRI to assess whether there is sufficient evidence to conclude that WML and brain atrophy are associated with each other independently of shared risk factors. Finally, we discussed the proposed mechanisms that could underlie the relation between WML and brain atrophy.

\section{Methods}

We searched PubMed for studies published in English between 1980 and October 2007. Since several synonyms exist for WML and brain atrophy, we made search terms for WML and brain atrophy and entered them as follows: ('search term for WML' AND 'search term for brain atrophy'). We combined this search with limits for language and publication date (fig. 1). The
Search term for white matter lesions:

('leukoaraiosis' [MeSH] OR leukoaraiosis [TIAB] OR leukoaraiosis [TIAB] OR white matter hyperintense [TIAB] OR white matter hyperintensity [TIAB] OR white matter hyperintensities [TIAB] OR white matter lesion [TIAB] OR white matter lesions [TIAB] OR white matter change [TIAB] OR white matter changes [TIAB] OR white matter abnormality [TIAB] OR white matter abnormalities [TIAB] OR white matter signal [TIAB] OR white matter signals [TIAB])

Search term for brain atrophy:

(((ventricle [TIAB] OR ventricles [TIAB] OR ventricular [TIAB] OR sulcus [TIAB] OR sulci [TIAB] OR sulcal [TIAB]) AND (enlargement [TIAB] OR size [TIAB] OR dilatation [TIAB] OR expansion [TIAB])) OR (('atrophy' [MeSH] OR atrophy [TIAB]) AND ('brain' [MeSH] OR brain [TIAB] OR cerebral [TIAB] OR hippocampus [TIAB] OR hippocampal [TIAB] OR cortical [TIAB] OR subcortical [TIAB] OR entorhinal cortex [TIAB] OR medial temporal lobe [TIAB])))

Limits

English [language] AND ('1980/01/01' [EDAT]: '2007/10/31' [EDAT])

$[\mathrm{TIAB}]=$ Title/Abstract; $[\mathrm{MeSH}]=$ Medical Subjects Heading; $[$ EDAT $]=$ Entry date, the date the citation was added to PubMed.

Fig. 1. Search terms and limits used for retrieval of relevant articles.

last search was performed on October 31st, 2007. Additional literature was obtained from reference lists of relevant articles.

One investigator (A.P.A.A.) screened all titles and abstracts, and all full-text articles were evaluated by 2 investigators independently of each other (A.P.A.A. and L.G.E.). A consensus meeting was held for cases of disagreement. Since we used a broad search term, we expected a large number of irrelevant articles. Therefore, we defined the following exclusion criteria on the basis of which abstracts could be discarded: case reports and reviews, studies performed in a pediatric study population, and studies in which only computed tomography (CT) was used for imaging. Since we were interested in WML of possible ischemic origin, we also excluded studies that investigated hyperintensities on MRI with other known causes (hematological disorders, metabolic or toxic causes, non-infectious inflammatory or autoimmune diseases, infectious causes, genetic disorders, radiotherapy or chemotherapy, and head trauma).

For all potentially relevant articles, we retrieved the full-text version. Data was extracted from the articles if they met the following criteria: (1) the relation between WML and brain atrophy 
was studied, (2) the report was published in English, (3) it was an original study, (4) MRI was used for imaging, (5) assessment methods for WML and brain atrophy were specified, and (6) a sample size of at least 20 participants per study group was defined.

For all relevant studies, we recorded the source population, the design (cross-sectional or longitudinal), the sample size, and the mean age of the participants. Next, we described the types of WML and measures of brain atrophy that were investigated and the methods that were used to assess WML and atrophy. Due to heterogeneity in the assessment of WML and brain atrophy, and due to variation in the units of measurements, it proved difficult to compare the measures of effect across studies quantitatively. Therefore, we decided to summarize the results qualitatively and recorded whether the relation between WML and measures of atrophy was statistically significant $(\mathrm{p}<0.05)$. If different subtypes of WML or brain atrophy were investigated within 1 study, we recorded the results separately. Finally, we checked whether adjustments were made for potential shared risk factors in the analyses, and recorded the variables for which adjustments were made.

\section{Results}

Our search resulted in 689 articles. As expected, the majority of these articles were not relevant for this review because we used a broad search term. After screening of the titles and abstracts, we retrieved the full-text version of 145 articles. Of these, 41 met the inclusion criteria and 7 additional relevant articles were identified through reference lists of the included articles. The most important reason why articles were excluded was because WML and brain atrophy were both studied as the determinant or as the outcome of interest, but the relation between them was not investigated.

The source populations were very heterogeneous. However, the study populations in the individual studies were more homogeneous. As both WML and brain atrophy are associated with vascular disease and cognitive impairment, the majority of the original studies limited their study populations to either patients from one of these categories or to individuals from the general population. We classified the 48 included articles into 3 main categories to preserve the categorization made in the original studies: general population, subjects with cognitive impairment, and patients with vascular disease.

The general population category consisted of studies that investigated a community-dwelling population or studies that were performed in healthy controls or in patients without neurological or psychiatric disease. In the category of patients with cognitive impairment, study populations were included with (probable) Alz- heimer's disease, mixed dementia or cognitive impairment without dementia. In 1 study, patients with Lewy body dementia were also included [31]. Studies investigating patients with vascular disease were further divided into a group of patients with vascular risk factors only and a group with clinically manifest cerebrovascular disease.

We also distinguished studies that investigated indicators of global brain atrophy from studies that investigated indicators of regional brain atrophy. Measures of global brain atrophy included total brain atrophy, cortical gray matter atrophy, white matter atrophy, and ventricular enlargement. The main measure of regional atrophy was medial temporal lobe atrophy (MTA), including atrophy of the hippocampus, amygdala, and entorhinal cortex.

Studies in which several study populations were investigated and studies reporting on the relation between WML and both global and regional brain atrophy were described in all relevant categories.

\section{General Population}

The characteristics and results of the 20 general population studies are summarized in table 1 . There were 17 cross-sectional studies [9, 13, 22, 32-45], 2 longitudinal studies $[46,47]$ and 1 study is included twice in table 1 , since both cross-sectional and longitudinal results were reported [48].

Thirteen studies involved a community-based study sample $[9,13,22,32,33,35,37,38,41,43,45-47]$, while 5 studies involved healthy controls or hospital personnel [34, 36, 40, 44, 48]. Two studies included neurologically healthy patients with different amounts of WML [39, 42].

Of the 13 cross-sectional studies that investigated global atrophy, 10 found a significant relation between more WML and more global brain atrophy [9, 13, 32-39]. This relation was also observed in the 2 longitudinal studies investigating global atrophy $[46,47]$. Of the 5 cross-sectional studies that examined regional brain atrophy, 3 studies found that WML were associated with more medial temporal lobe atrophy and with smaller hippocampal and amygdala volumes [40-42]. However, in the 2 other cross-sectional studies there was no association between WML and hippocampal atrophy [43], or hippocampal and entorhinal volumes [48]. Also, WML volume at baseline was not associated with the atrophy rates of the entorhinal cortex and hippocampus during follow-up [48]. 


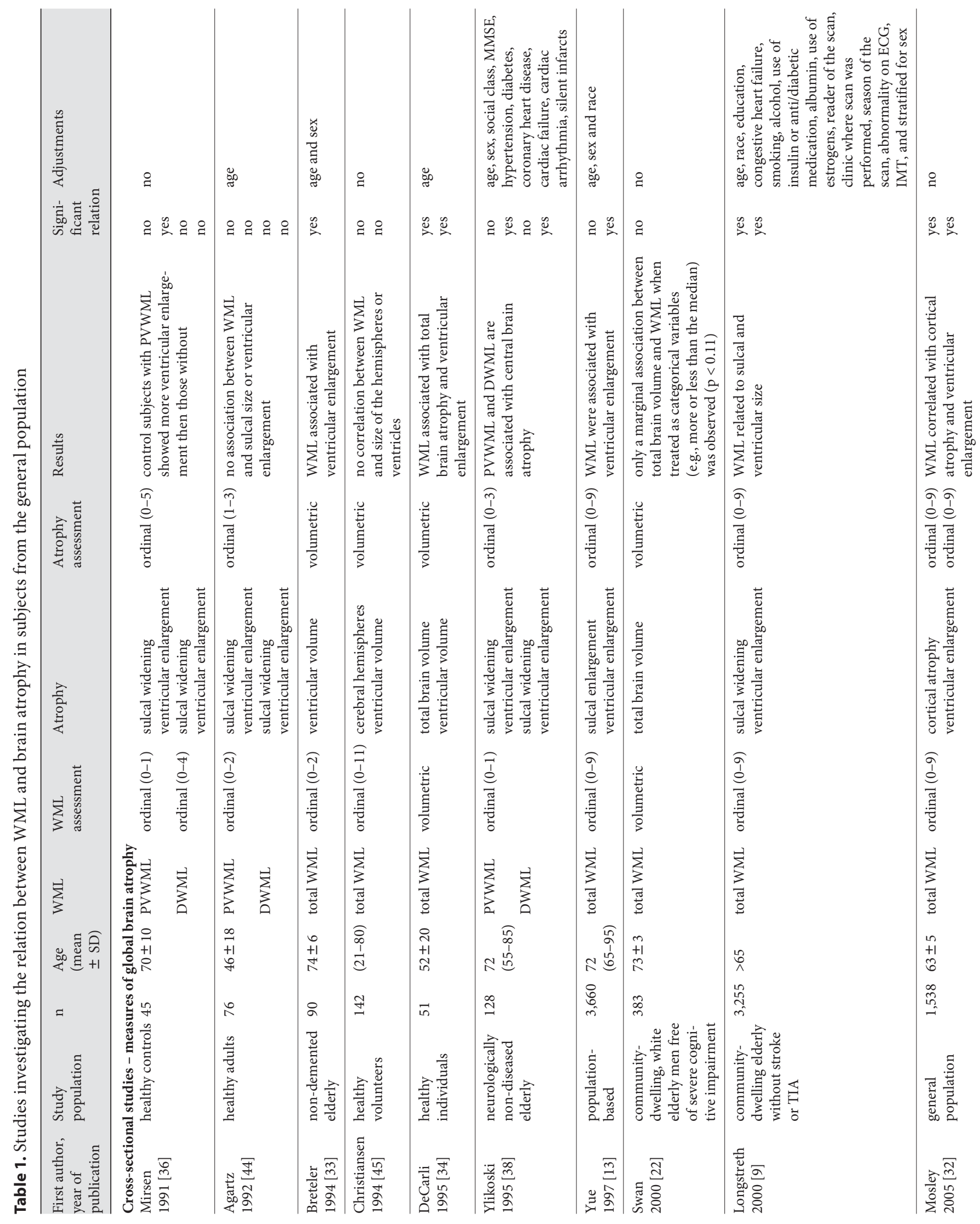




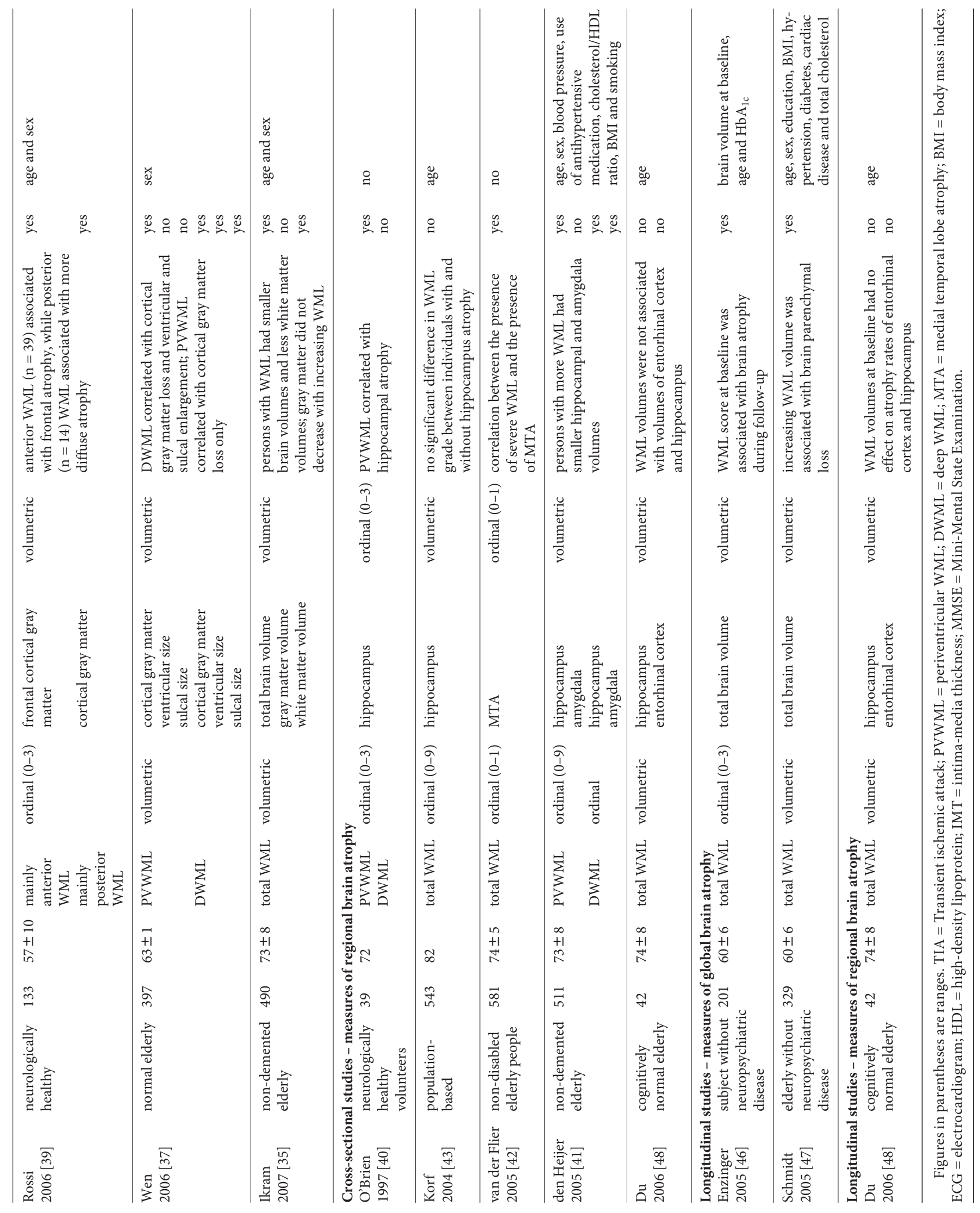




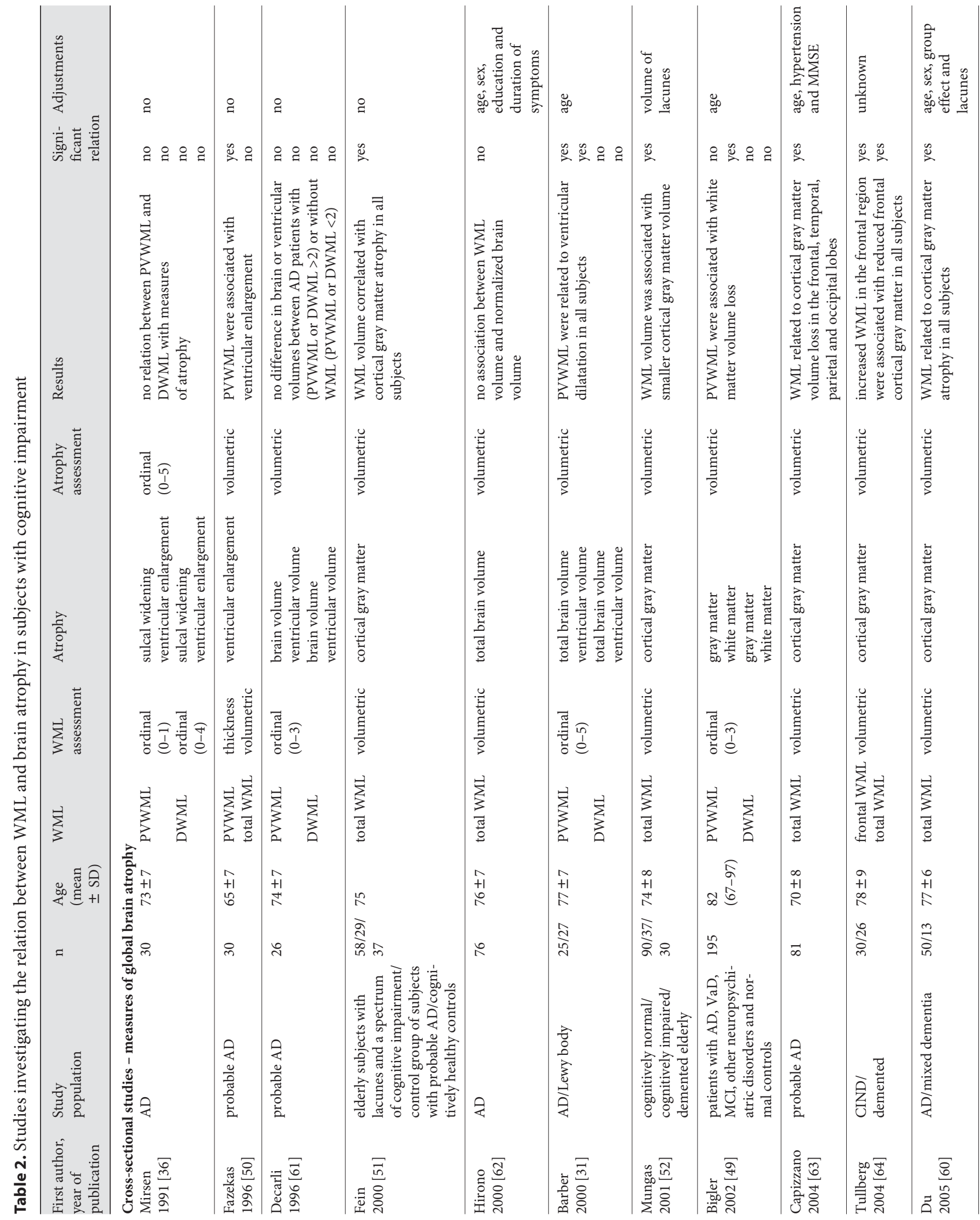




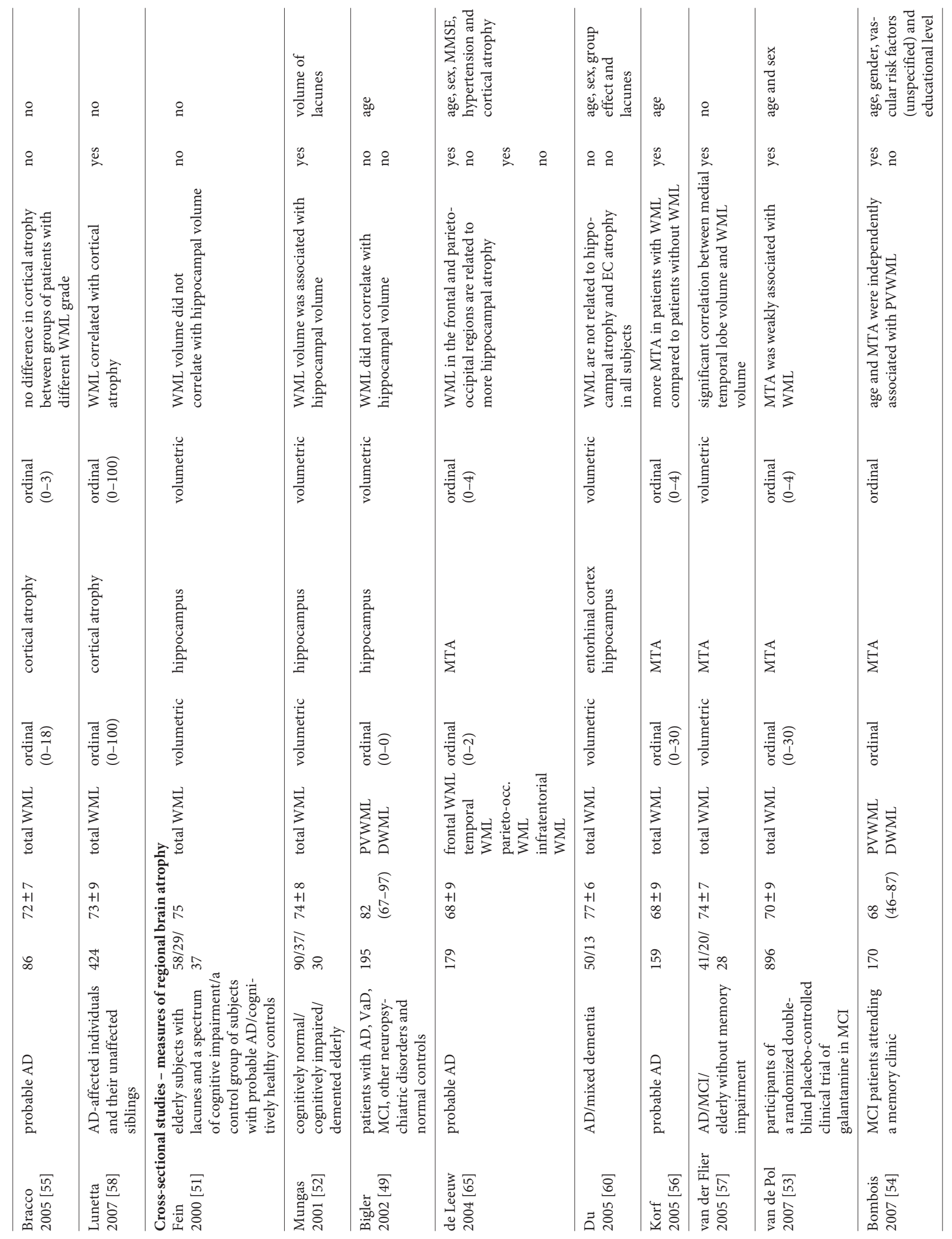




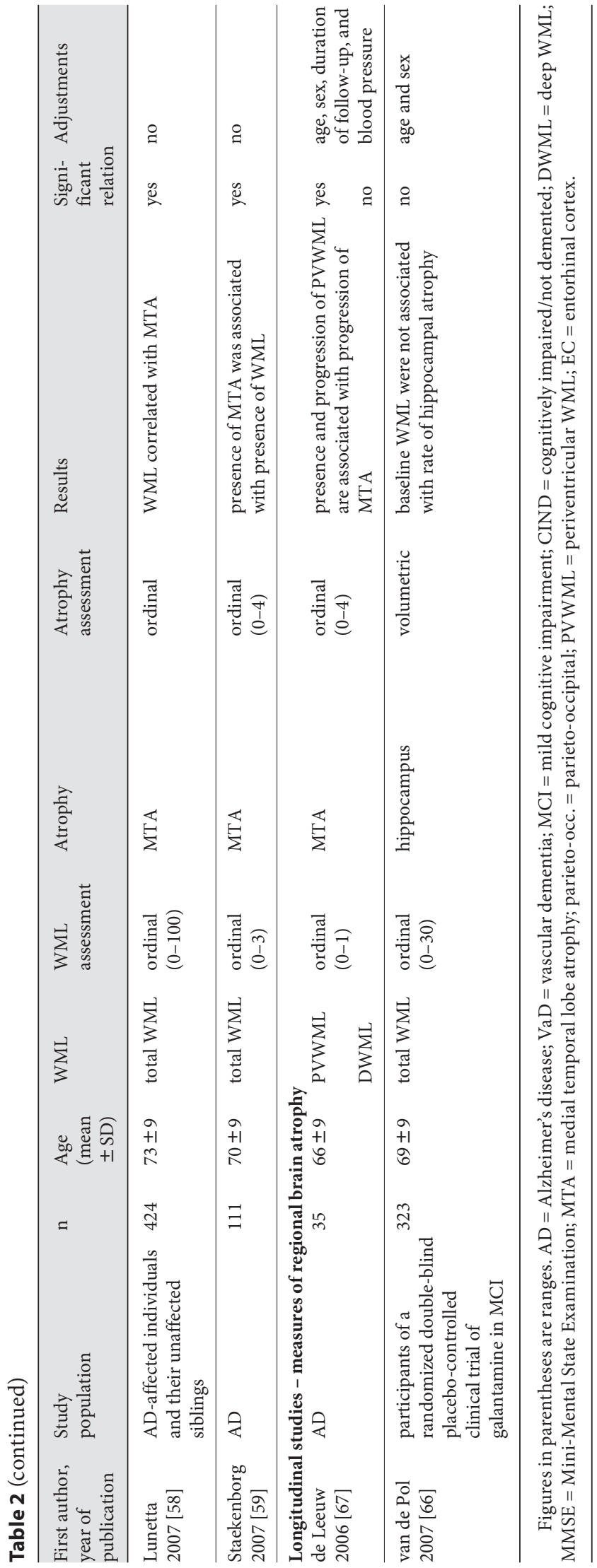

In 7 of the 20 general population studies, no adjustments were made for age [22, 32, 36, 37, 40, 42, 45]. Shared risk factors were only considered in 4 out of 20 studies [9, $38,41,47$ ], all of which observed an association between WML and measures of brain atrophy.

\section{Subjects with Cognitive Impairment}

Nineteen cross-sectional studies [31, 36, 49-65] and 2 longitudinal studies $[66,67]$ were performed in patients with cognitive impairment. Characteristics and results of these studies are presented in table 2. In 5 studies [49, 51, $52,58,60]$, both global and regional brain atrophy were investigated, and therefore these studies are presented twice in table 2.

Study populations consisted of patients referred for evaluation of cognitive impairment or dementia [31, 36, $49,50,54-57,59,62,63]$ or of patients who were recruited at specialized dementia centers [52, 60, 64, 65, 67]. Two studies were performed in MCI patients participating in a clinical trial $[53,66]$, one study was part of a large genetic study in AD patients and their non-demented siblings [58], and in the other study participants were selected because they met the criteria for probable $\mathrm{AD}$ and did or did not show severe WML on MRI [61]. Finally, 1 study was performed in a heterogeneous group of patients with lacunes and a spectrum of cognitive impairment, in patients with probable $\mathrm{AD}$ without lacunes, and a control group of individuals without cognitive impairment and without lacunes [51].

The relation between WML and global brain atrophy was assessed in 13 cross-sectional studies. In 9 of these, WML were associated with more global brain atrophy and with smaller cortical gray matter volumes [31, 49$52,58,60,63,64]$. In the other 4 studies, these relations were not found $[36,55,61,62]$. The relation between WML and measures of regional brain atrophy was investigated in 11 cross-sectional studies and in 2 longitudinal studies. A significant association between WML and atrophy of the hippocampus or medial temporal lobe was found in 7 cross-sectional studies [52-54, 56-59], although in 1 of these studies only periventricular WML, and not deep WML, were associated with medial temporal lobe atrophy [54]. In another cross-sectional study [65], a relation was found between WML in the frontal and parieto-occipital regions and more hippocampal atrophy. In 3 cross-sectional studies [49, 51, 60], no relation was found between total WML volume or WML ratings and volumes of the hippocampus or entorhinal cortex. In 1 longitudinal study, presence and progression of periventricular WML, but not deep WML, were associ- 
ated with progression of medial temporal lobe atrophy [67]. In another longitudinal study, total WML volume at baseline was not associated with the rate of hippocampal atrophy [66].

In 10 studies, no adjustments were made for potential shared risk factors in the relation between WML and atrophy $[36,50-52,55,57-59,61,64]$. Adjustments for age or sex were made in the remaining 11 studies. Three considered hypertension or blood pressure as a possible shared risk factor [63, 65, 67]. In 1 study [54], adjustments were made for vascular risk factors, without further specification. Therefore, although in the last 4 studies associations between WML and brain atrophy were found, it is unknown whether these associations are also independent of other vascular risk factors.

\section{Patients with Vascular Risk Factors or Symptomatic} Vascular Disease

The characteristics and results of the 4 studies [68-71] performed in patients with vascular risk factors are presented in table $3 \mathrm{a}$ and the characteristics and results of the 4 studies [72-75] performed in patients with symptomatic cerebrovascular disease are given in table $3 \mathrm{~b}$. Of these 8 studies, 5 examined the cross-sectional and 3 the longitudinal relation between WML and atrophy. Two cross-sectional studies $[70,72]$ examined global as well as regional atrophy. Furthermore, 1 study [74] reported the cross-sectional relation between WML and medial temporal lobe atrophy and the longitudinal relation between WML and ventricular enlargement.

The 4 studies that investigated a population with vascular risk factors recruited their patients from outpatient clinics [68-70] or from a trial on antihypertensive drugs [71]. The studies that investigated patients with manifest cerebrovascular disease included stroke survivors 3 months after discharge $[72,74]$, patients with a transient ischemic attack [75], and patients with a lacunar stroke [73].

In 2 cross-sectional studies performed in patients with vascular risk factors, associations were found between larger volumes of periventricular WML and more global brain atrophy and both sulcal and ventricular enlargement $[68,69]$. However, in 2 other cross-sectional studies in hypertensive patients and normotensive controls, no associations between WML and total brain volume or hippocampal volume were found [70]. In a longitudinal study in hypertensive and normotensive elderly, there was no association between global atrophy rate and degree of WML at baseline, or change in WML severity during follow-up [71].

WML and Brain Atrophy
In the patients with stroke or TIA, cross-sectional associations were found between more WML and more cortical, central and medial temporal lobe atrophy [7275]. The relation between WML and ventricular enlargement was also found in the longitudinal study [74].

In 3 studies $[68,71,75]$, the analyses were adjusted for age. In 1 of these studies [75] there was an association between WML and brain atrophy after adjustment for systolic and diastolic blood pressure. However, there was no association between WML and brain atrophy in another study [71] in which adjustments were made for other vascular risk factors as well. In the remaining 5 studies, no adjustments were made for age, sex or other possible shared vascular risk factors $[69,70,72-74]$.

\section{Discussion}

We included 48 articles that investigated the relation between WML and measures of global or regional brain atrophy. A significant relation between WML and global brain atrophy was found in 12 out of 15 general population studies, 9 out of 13 studies in patients with cognitive impairment and in 6 out of 8 studies performed in patients with vascular risk factors or symptomatic cerebrovascular disease. A significant relation between WML and medial temporal lobe atrophy - including atrophy of the hippocampus, amygdala, and entorhinal cortex - was found in 3 out of 6 general population studies, 9 out of 13 studies in patients with cognitive impairment, and in 2 out of 3 studies performed in patients with vascular risk factors or symptomatic cerebrovascular disease.

The clinical observation that WML and brain atrophy are often seen simultaneously on MRI is thus confirmed by the majority of the retrieved articles. However, most of the studies did not adjust for possible shared risk factors. Moreover, in 22 of the 48 studies no adjustments were made for age. From these studies, it is not possible to conclude that the relation between WML and brain atrophy is independent of age. When we look at all the studies that did adjust for age and other risk factors, 9 out of 10 studies found that WML were associated with measures of brain atrophy, providing at least some evidence that the relation is independent of shared risk factors [9, $38,41,47,54,63,65,67,75]$.

Eight studies examined the longitudinal relation between WML and atrophy. Of these, 1 study did not adjust for age or other possible shared risk factors, 3 adjusted for age or age and sex, and 4 studies also adjusted for a small number of shared risk factors. Of the 7 longitudi-

Cerebrovasc Dis 2009;28:227-242 


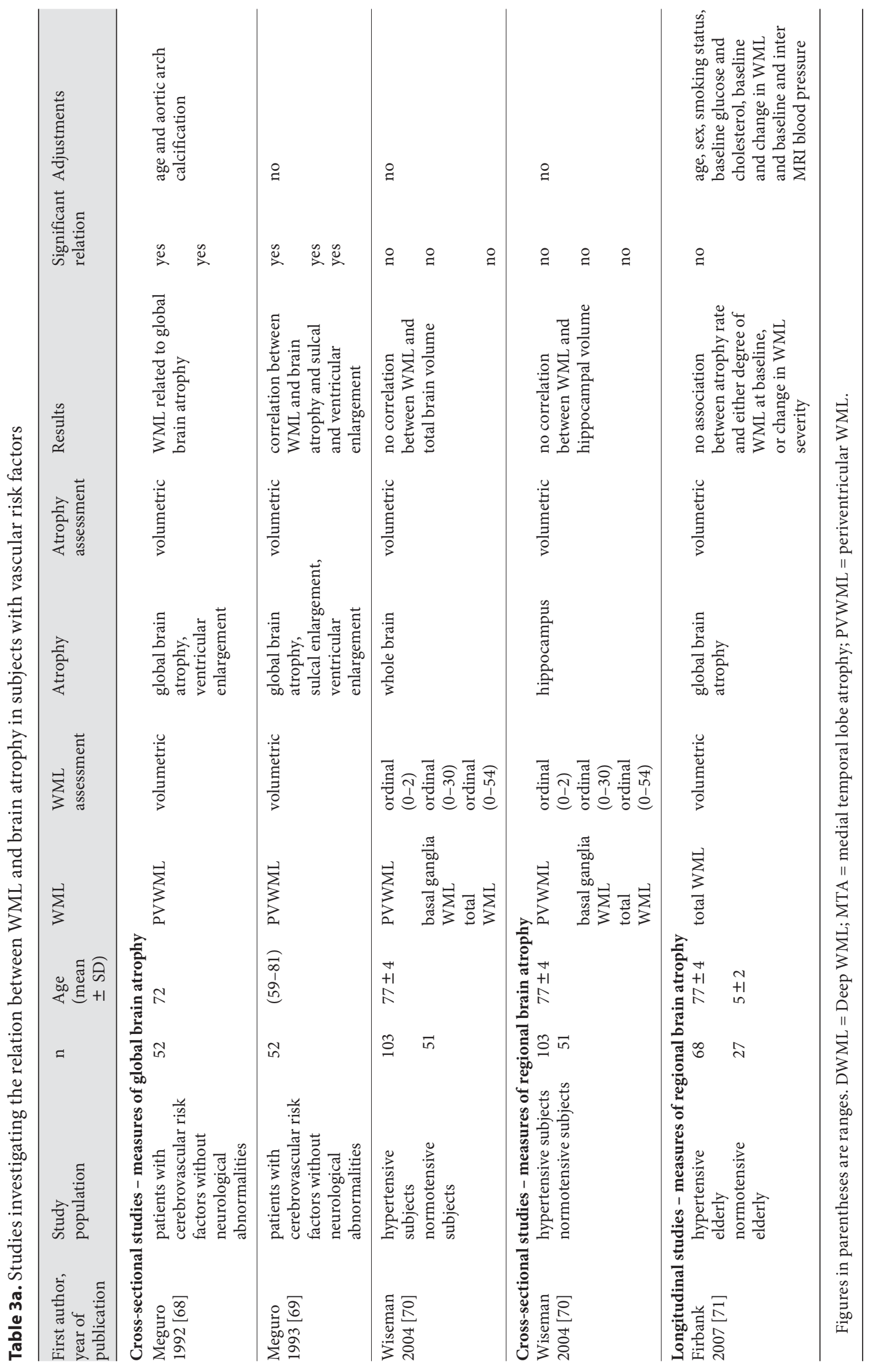




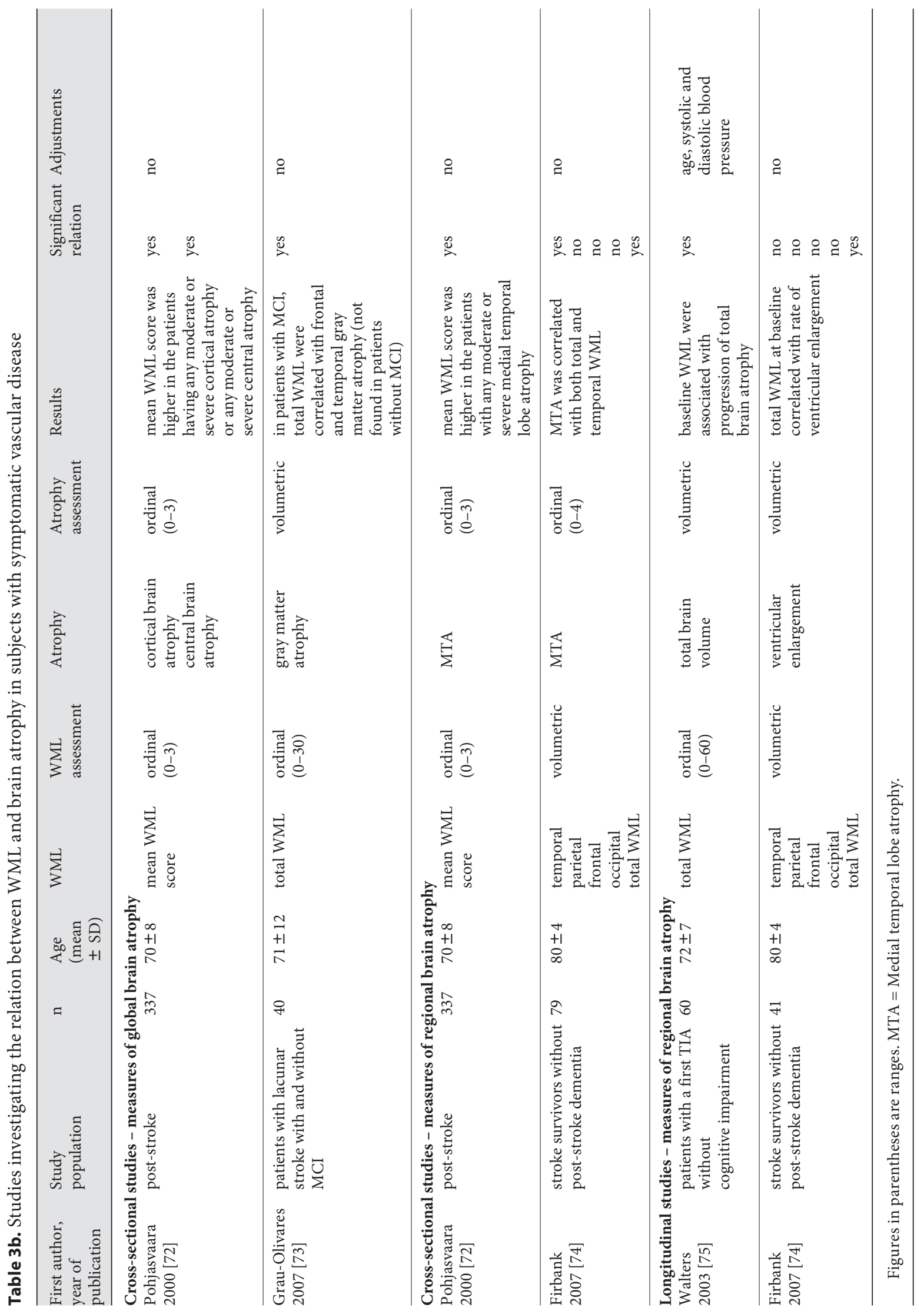


nal studies that adjusted for age or other factors, 4 found that WML were significantly associated with progression of brain atrophy, whereas 3 did not find an association. Thus, from the existing longitudinal studies, we cannot conclude that WML are a risk factor for brain atrophy.

An interesting pattern was observed when we compared the results of studies investigating global atrophy with the results of studies investigating regional brain atrophy. The majority of studies found an association between WML and global brain atrophy, which remained in the majority of the studies after adjustment for age and vascular risk factors. This association was also present in the majority of the longitudinal studies. The studies that did not find an association between WML and global atrophy generally had smaller sample sizes and used less accurate rating scales, which may have resulted in a low power to detect a significant relationship. In comparison, the results from the studies investigating the association between WML and measures of regional brain atrophy were less consistent. Interestingly, from the 12 studies that adjusted for age or other factors, all 5 studies that used the MTA score found a significant association with WML, while the 7 studies that used volumetric measurements of the hippocampus did not, except for 1 study, find an association with WML. Since the MTA score not only visually assesses volume of the medial temporal lobe, but also volume of the temporal horn of the lateral ventricle and the choroid fissure, it is plausible that concomitant ventricular enlargement accounts for the observed association between WML and MTA score [76]. Support for this explanation comes from a study that found that the MTA score correlated better with the volume of the lateral ventricle than with the volume of the medial temporal lobe itself [77].

Several mechanisms have been proposed that may explain an association between WML and brain atrophy. One possible mechanism is loss of myelin, axons, and oligodendrocytes and other glial cells in the subcortical white matter as a result of ischemic damage due to the underlying small-vessel disease [30,78]. The association of WML with cortical gray matter atrophy may possibly be explained by ischemic damage to the axons in the subcortical white matter leading to deafferentation of cortical-subcortical connections and subsequent cortical neurodegeneration [60]. Similar mechanisms have been proposed to explain the relation between WML and atrophy of the hippocampus and amygdala, and consequently the medial temporal lobe $[41,65]$. Ischemia due to the cerebral small-vessel disease may well damage the axons in the white matter, which eventually could lead to shrinkage of the hippocampus as a result of Wallerian degeneration [79]. Another explanation that has been proposed is that an impaired autoregulation due to the microangiopathy in combination with the luminal narrowing reduces the cerebral blood flow [80]. Since the hippocampus and amygdala are sensitive to hypoxia and ischemia $[81,82]$, this ischemia may then lead to loss of the neurons in these brain structures [83].

Other observations that may support an association between WML and brain atrophy have come from studies in other neurological conditions, such as CADASIL (cerebral autosomal dominant arteriopathy with subcortical infarcts and leukoencephalopathy), multiple sclerosis [84], amyotrophic lateral sclerosis [85], and HIV [86]. Of these conditions, CADASIL is of particular interest, because the WML in that condition are also presumed to be due to vascular disease [87]. Apart from widespread WML and lacunar infarcts, brain atrophy is also a hallmark of this disease [88]. Furthermore, both hippocampal atrophy [89], subcortical atrophy [90], and global brain atrophy [91] are important predictors of cognitive performance in CADASIL patients. However, volume of WML was not associated with extent of hippocampal [89] or global brain atrophy $[88,90]$, although this can potentially be explained by the small sample sizes of studies in patients with CADASIL.

Given the plausible biological hypotheses, but inconsistent results, more research is warranted. Future studies should preferably assess WML as well as brain atrophy volumetrically. Visual rating scales are impeded by floor and ceiling effects and their reliability is often limited [92]. Volumetric measurements offer a more reliable, sensitive, and also objective alternative to visual rating scales [93]. However, in case volumetric assessment of WML in longitudinal studies is not feasible, at least dedicated longitudinal visual scales should be used [94]. In addition, quantitative measurements of WML and brain volumes should be normalized for head size [95]. This facilitates comparison between studies and also helps in overcoming the difficulty of interpreting the strength of the relation. Analyses on the association between WML and atrophy should at least take the effects of age and sex into account, but should also address shared vascular risk factors. Another factor that should be considered is the presence or number of lacunar infarcts. Lacunar infarcts are also considered to be caused by cerebral small-vessel disease and are also often found on MRI in the elderly [9698]. In patients with Alzheimer's disease and mixed dementia, lacunar infarcts may be associated with subcorti- 
cal brain atrophy $[60,99]$. Furthermore, in studies that examine the association between WML and atrophy of the medial temporal lobe or structures herein, global brain atrophy should be taken into account to assess whether an association is explained by global brain atrophy. Finally, to properly address the issue of the directionality of the association between WML and brain atrophy, future studies should have a longitudinal design.
In conclusion, the majority of studies found an association between WML and global brain atrophy, but it is yet uncertain if this association is independent of shared risk factors. Further studies on the relation between WML and brain atrophy are therefore warranted and should make proper adjustments in the analysis, preferably be longitudinal in design, and use volumetric assessment of WML and brain atrophy.

\section{References}

1 Fotenos AF, Snyder AZ, Girton LE, Morris JC, Buckner RL: Normative estimates of cross-sectional and longitudinal brain volume decline in aging and AD. Neurology 2005;64:1032-1039.

-2 Ge Y, Grossman RI, Babb JS, Rabin ML, Mannon LJ, Kolson DL: Age-related total gray matter and white matter changes in normal adult brain. 1. Volumetric MR imaging analysis. AJNR Am J Neuroradiol 2002;23: 1327-1333.

>3 Scahill RI, Frost C, Jenkins R, Whitwell JL, Rossor MN, Fox NC: A longitudinal study of brain volume changes in normal aging using serial registered magnetic resonance imaging. Arch Neurol 2003;60:989-994.

4 Jack CR Jr, Shiung MM, Weigand SD, O’Brien PC, Gunter JL, Boeve BF, Knopman DS, Smith GE, Ivnik RJ, Tangalos EG, Petersen RC: Brain atrophy rates predict subsequent clinical conversion in normal elderly and amnestic MCI. Neurology 2005;65:12271231.

5 Mungas D, Reed BR, Jagust WJ, DeCarli C, Mack WJ, Kramer JH, Weiner MW, Schuff N, Chui HC: Volumetric MRI predicts rate of cognitive decline related to AD and cerebrovascular disease. Neurology 2002;59:867873.

6 den Heijer T, Geerlings MI, Hoebeek FE, Hofman A, Koudstaal PJ, Breteler MM: Use of hippocampal and amygdalar volumes on magnetic resonance imaging to predict dementia in cognitively intact elderly people. Arch Gen Psychiatry 2006;63:57-62.

7 Goldstein IB, Bartzokis G, Guthrie D, Shapiro D: Ambulatory blood pressure and the brain: a 5-year follow-up. Neurology 2005; 64:1846-1852.

$\checkmark 8$ Meyer JS, Rauch GM, Crawford K, Rauch RA, Konno S, Akiyama H, Terayama Y, Haque A: Risk factors accelerating cerebral degenerative changes, cognitive decline and dementia. Int J Geriatr Psychiatry 1999;14: 1050-1061.
-9 Longstreth WT Jr, Arnold AM, Manolio TA, Burke GL, Bryan N, Jungreis CA, O’Leary D, Enright PL, Fried L: Clinical correlates of ventricular and sulcal size on cranial magnetic resonance imaging of 3,301 elderly people. The Cardiovascular Health Study. Collaborative Research Group. Neuroepidemiology 2000;19:30-42.

10 Gustafson D, Lissner L, Bengtsson C, Bjorkelund C, Skoog I: A 24-year follow-up of body mass index and cerebral atrophy. Neurology 2004;63:1876-1881.

11 Ding J, Eigenbrodt ML, Mosley TH Jr, Hutchinson RG, Folsom AR, Harris TB, Nieto FJ: Alcohol intake and cerebral abnormalities on magnetic resonance imaging in a community-based population of middle-aged adults: the Atherosclerosis Risk in Communities (ARIC) Study. Stroke 2004;35:16-21.

12 Manolio TA, Kronmal RA, Burke GL, Poirier V, O'Leary DH, Gardin JM, Fried LP, Steinberg EP, Bryan RN: Magnetic resonance abnormalities and cardiovascular disease in older adults. The Cardiovascular Health Study. Stroke 1994;25:318-327.

13 Yue NC, Arnold AM, Longstreth WT Jr, Elster AD, Jungreis CA, O'Leary DH, Poirier VC, Bryan RN: Sulcal, ventricular, and white matter changes at MR imaging in the aging brain: data from the cardiovascular health study. Radiology 1997;202:33-39.

14 Longstreth WT, Manolio TA, Arnold A, Burke GL, Bryan N, Jungreis CA, Enright PL, O'Leary D, Fried L: Clinical correlates of white matter findings on cranial magnetic resonance imaging of 3301 elderly people: the Cardiovascular Health Study. Stroke 1996;27:1274-1282.

15 Reed BR, Eberling JL, Mungas D, Weiner M, Kramer JH, Jagust WJ: Effects of white matter lesions and lacunes on cortical function. Arch Neurol 2004;61:1545-1550.

16 van der Flier WM, van Straaten ECW, Barkhof F, Verdelho A, Madureira S, Pantoni L, Inzitari D, Erkinjuntti T, Crisby M, Waldemar G, Schmidt R, Fazekas F, Scheltens P, LADIS Study Group: Small vessel disease and general cognitive function in nondisabled elderly: the LADIS Study. Stroke 2005; 36:2116-2120.
7 Prins ND, van Dijk EJ, den Heijer T, Vermeer SE, Jolles J, Koudstaal PJ, Hofman A, Breteler MM: Cerebral small-vessel disease and decline in information processing speed, executive function and memory. Brain 2005;128: 2034-2041.

18 Breteler MM, van Swieten JC, Bots ML, Grobbee DE, Claus JJ, van den Hout JH, van Harskamp F, Tanghe HL, de Jong PT, van Gijn J: Cerebral white matter lesions, vascular risk factors, and cognitive function in a population-based study: the Rotterdam Study. Neurology 1994;44:1246-1252.

19 Jokinen H, Kalska H, Ylikoski R, Madureira S, Verdelho A, van der Flier WM, Scheltens P, Barkhof F, Visser MC, Fazekas F, Schmidt R, O’Brien J, Waldemar G, Wallin A, Chabriat $\mathrm{H}$, Pantoni $\mathrm{L}$, Inzitari $\mathrm{D}$, Erkinjuntti $\mathrm{T}$ : Longitudinal cognitive decline in subcortical ischemic vascular disease - the LADIS Study. Cerebrovasc Dis 2009;27:384-391.

20 Jokinen H, Kalska H, Ylikoski R, Madureira S, Verdelho A, Gouw A, Scheltens P, Barkhof F, Visser MC, Fazekas F, Schmidt R, O'Brien J, Hennerici M, Baezner H, Waldemar G, Wallin A, Chabriat H, Pantoni L, Inzitari D, Erkinjuntti T: MRI-defined subcortical ischemic vascular disease: baseline clinical and neuropsychological findings. The LADIS Study. Cerebrovasc Dis 2009;27:336-344.

-21 DeCarli C, Miller BL, Swan GE, Reed T, Wolf PA, Garner J, Jack L, Carmelli D: Predictors of brain morphology for the men of the NHLBI twin study. Stroke 1999;30:529-536.

22 Swan GE, DeCarli C, Miller BL, Reed T, Wolf PA, Carmelli D: Biobehavioral characteristics of nondemented older adults with subclinical brain atrophy. Neurology 2000;54: 2108-2114.

23 Knopman DS, Mosley TH, Catellier DJ, Sharrett AR: Cardiovascular risk factors and cerebral atrophy in a middle-aged cohort. Neurology 2005;65:876-881.

24 Dufouil C, de Kersaint-Gilly A, Besancon V, Levy C, Auffray E, Brunnereau L, Alperovitch A, Tzourio C: Longitudinal study of blood pressure and white matter hyperintensities: the EVA MRI Cohort. Neurology 2001; 56:921-926. 
25 Dufouil C, Chalmers J, Coskun O, Besancon V, Bousser MG, Guillon P, MacMahon S, Mazoyer B, Neal B, Woodward M, TzourioMazoyer N, Tzourio C: Effects of blood pressure lowering on cerebral white matter hyperintensities in patients with stroke: the PROGRESS (Perindopril Protection Against Recurrent Stroke Study) Magnetic Resonance Imaging Substudy. Circulation 2005; 112:1644-1650

-26 van Harten B, Oosterman JM, Potter van Loon BJ, Scheltens P, Weinstein HC: Brain lesions on MRI in elderly patients with type 2 diabetes mellitus. Eur Neurol 2007;57:7074.

27 Gustafson DR, Steen B, Skoog I: Body mass index and white matter lesions in elderly women: an 18-year longitudinal study. Int Psychogeriatr 2004;16:327-336.

-28 Jagust W, Harvey D, Mungas D, Haan M: Central obesity and the aging brain. Arch Neurol 2005;62:1545-1548.

29 Roman GC: On the history of lacunes, etat crible, and the white matter lesions of vascular dementia. Cerebrovasc Dis 2002;13(suppl 2):1-6.

30 Pantoni L, Garcia JH: Pathogenesis of leukoaraiosis: a review. Stroke 1997;28:652-659.

-31 Barber R, Gholkar A, Scheltens P, Ballard C, McKeith IG, O'Brien JT: MRI volumetric correlates of white matter lesions in dementia with Lewy bodies and Alzheimer's disease. Int J Geriatr Psychiatry 2000;15:911916.

- 32 Mosley TH Jr, Knopman DS, Catellier DJ, Bryan N, Hutchinson RG, Grothues CA, Folsom AR, Cooper LS, Burke GL, Liao D, Szklo M: Cerebral MRI findings and cognitive functioning: the Atherosclerosis Risk in Communities Study. Neurology 2005;64: 2056-2062.

- 33 Breteler MM, van Amerongen NM, van Swieten JC, Claus JJ, Grobbee DE, van Gijn J, Hofman A, van Harskamp F: Cognitive correlates of ventricular enlargement and cerebral white matter lesions on magnetic resonance imaging. The Rotterdam Study. Stroke 1994:25:1109-1115.

- 34 DeCarli C, Murphy DG, Tranh M, Grady CL, Haxby JV, Gillette JA, Salerno JA, GonzalesAviles A, Horwitz B, Rapoport SI: The effect of white matter hyperintensity volume on brain structure, cognitive performance, and cerebral metabolism of glucose in 51 healthy adults. Neurology 1995;45:2077-2084

- 35 Ikram MA, Vrooman HA, Vernooij MW, van der Lijn F, Hofman A, van der Lugt A, Niessen WJ, Breteler MM: Brain tissue volumes in the general elderly population The Rotterdam Scan Study. Neurobiol Aging 2008;29:882-890.

- 36 Mirsen TR, Lee DH, Wong CJ, Diaz JF, Fox AJ, Hachinski VC, Merskey H: Clinical correlates of white-matter changes on magnetic resonance imaging scans of the brain. Arch Neurol 1991;48:1015-1021.
37 Wen W, Sachdev PS, Chen X, Anstey K: Gray matter reduction is correlated with white matter hyperintensity volume: a voxel-based morphometric study in a large epidemiological sample. Neuroimage 2006;29:10311039.

38 Ylikoski A, Erkinjuntti T, Raininko R, Sarna S, Sulkava R, Tilvis R: White matter hyperintensities on MRI in the neurologically nondiseased elderly. Analysis of cohorts of consecutive subjects aged 55 to 85 years living at home. Stroke 1995;26:1171-1177.

39 Rossi R, Boccardi M, Sabattoli F, Galluzzi S, Alaimo G, Testa C, Frisoni GB: Topographic correspondence between white matter hyperintensities and brain atrophy. J Neurol 2006;253:919-927.

40 O’Brien JT, Desmond P, Ames D, Schweitzer I, Tress B: Magnetic resonance imaging correlates of memory impairment in the healthy elderly: association with medial temporal lobe atrophy but not white matter lesions. Int J Geriatr Psychiatry 1997;12:369-374.

41 den Heijer T, Launer LJ, Prins ND, van Dijk EJ, Vermeer SE, Hofman A, Koudstaal PJ, Breteler MM: Association between blood pressure, white matter lesions, and atrophy of the medial temporal lobe. Neurology 2005;64:263-267.

42 van der Flier WM, van Straaten EC, Barkhof F, Ferro JM, Pantoni L, Basile AM, Inzitari D, Erkinjuntti T, Wahlund LO, Rostrup E, Schmidt R, Fazekas F, Scheltens P: Medial temporal lobe atrophy and white matter hyperintensities are associated with mild cognitive deficits in non-disabled elderly people: the LADIS study. J Neurol Neurosurg Psychiatry 2005;76:1497-1500.

43 Korf ESC, White LR, Scheltens P, Launer LJ: Midlife blood pressure and the risk of hippocampal atrophy. The Honolulu Asia Aging Study. Hypertension 2004;44:29-34.

44 Agartz I, Marions O, Saaf J, Wahlund LO, Wetterberg L: Visual rating of magnetic resonance images of human cerebrospinal fluid spaces and white brain matter: relation to sex and age in healthy volunteers. Magn Reson Imaging 1992;10:135-142.

45 Christiansen P, Larsson HB, Thomsen C, Wieslander SB, Henriksen O: Age dependent white matter lesions and brain volume changes in healthy volunteers. Acta Radiol 1994;35:117-122.

-46 Enzinger C, Fazekas F, Matthews PM, Ropele S, Schmidt H, Smith S, Schmidt R: Risk factors for progression of brain atrophy in aging: six-year follow-up of normal subjects. Neurology 2005;64:1704-1711.

47 Schmidt R, Ropele S, Enzinger C, Petrovic K Smith S, Schmidt H, Matthews PM, Fazekas F: White matter lesion progression, brain atrophy, and cognitive decline: the Austrian stroke prevention study. Ann Neurol 2005; 58:610-616.
48 Du AT, Schuff N, Chao LL, Kornak J, Jagust WJ, Kramer JH, Reed BR, Miller BL, Norman D, Chui HC, Weiner MW: Age effects on atrophy rates of entorhinal cortex and hippocampus. Neurobiol Aging 2006;27: 733-740.

49 Bigler ED, Kerr B, Victoroff J, Tate DF, Breitner JC: White matter lesions, quantitative magnetic resonance imaging, and dementia. Alzheimer Dis Assoc Disord 2002; 16:161-170.

50 Fazekas F, Kapeller P, Schmidt R, Offenbacher H, Payer F, Fazekas G: The relation of cerebral magnetic resonance signal hyperintensities to Alzheimer's disease. J Neurol Sci 1996;142:121-125.

51 Fein G, Di Sclafani V, Tanabe J, Cardenas V, Weiner MW, Jagust WJ, Reed BR, Norman D, Schuff N, Kusdra L, Greenfield T, Chui H: Hippocampal and cortical atrophy predict dementia in subcortical ischemic vascular disease. Neurology 2000;55:1626-1635.

-52 Mungas D, Jagust WJ, Reed BR, Kramer JH, Weiner MW, Schuff N, Norman D, Mack WJ, Willis L, Chui HC: MRI predictors of cognition in subcortical ischemic vascular disease and Alzheimer's disease. Neurology 2001;57: 2229-2235.

53 van de Pol LA, Korf ES, van der Flier WM, Brashear HR, Fox NC, Barkhof F, Scheltens $\mathrm{P}$ : Magnetic resonance imaging predictors of cognition in mild cognitive impairment. Arch Neurol 2007;64:1023-1028.

54 Bombois S, Debette S, Delbeuck X, Bruandet A, Lepoittevin S, Delmaire C, Leys D, Pasquier F: Prevalence of subcortical vascular lesions and association with executive function in mild cognitive impairment subtypes. Stroke 2007;38:2595-2597.

55 Bracco L, Piccini C, Moretti M, Mascalchi M, Sforza A, Nacmias B, Cellini E, Bagnoli S, Sorbi S: Alzheimer's disease: role of size and location of white matter changes in determining cognitive deficits. Dement Geriatr Cogn Disord 2005;20:358-366.

56 Korf ES, Scheltens P, Barkhof F, de Leeuw FE: Blood pressure, white matter lesions and medial temporal lobe atrophy: closing the gap between vascular pathology and Alzheimer's disease? Dement Geriatr Cogn Disord 2005; 20:331-337.

57 van der Flier WM, Middelkoop HA, Weverling-Rijnsburger AW, Admiraal-Behloul F, Bollen EL, Westendorp RG, van Buchem MA: Neuropsychological correlates of MRI measures in the continuum of cognitive decline at old age. Dement Geriatr Cogn Disord 2005;20:82-88.

58 Lunetta KL, Erlich PM, Cuenco KT, Cupples LA, Green RC, Farrer LA, DeCarli C: Heritability of magnetic resonance imaging (MRI) traits in Alzheimer disease cases and their siblings in the MIRAGE study. Alzheimer Dis Assoc Disord 2007;21:85-91. 
-59 Staekenborg SS, Gillissen F, Romkes R, Pijnenburg YA, Barkhof F, Scheltens P, van der Flier WM: Behavioural and psychological symptoms are not related to white matter hyperintensities and medial temporal lobe atrophy in Alzheimer's disease. Int J Geriatr Psychiatry 2007;23:387-392.

-60 Du AT, Schuff N, Chao LL, Kornak J, Ezekiel F, Jagust WJ, Kramer JH, Reed BR, Miller BL, Norman D, Chui HC, Weiner MW: White matter lesions are associated with cortical atrophy more than entorhinal and hippocampal atrophy. Neurobiol Aging 2005;26:553559.

-61 DeCarli C, Grady CL, Clark CM, Katz DA, Brady DR, Murphy DG, Haxby JV, Salerno JA, Gillette JA, Gonzalez-Aviles A, Rapoport SI: Comparison of positron emission tomography, cognition, and brain volume in Alzheimer's disease with and without severe abnormalities of white matter. J Neurol Neurosurg Psychiatry 1996;60:158-167.

-62 Hirono N, Kitagaki H, Kazui H, Hashimoto M, Mori E: Impact of white matter changes on clinical manifestation of Alzheimer's disease: a quantitative study. Stroke 2000;31: 2182-2188.

-63 Capizzano AA, Acion L, Bekinschtein T, Furman M, Gomila H, Martinez A, Mizrahi $\mathrm{R}$, Starkstein SE: White matter hyperintensities are significantly associated with cortical atrophy in Alzheimer's disease. J Neurol Neurosurg Psychiatry 2004;75:822-827.

64 Tullberg M, Fletcher E, DeCarli C, Mungas D, Reed BR, Harvey DJ, Weiner MW, Chui HC, Jagust WJ: White matter lesions impair frontal lobe function regardless of their location. Neurology 2004;63:246-253.

65 de Leeuw FE, Barkhof F, Scheltens P: White matter lesions and hippocampal atrophy in Alzheimer's disease. Neurology 2004;62: 310-312.

66 van de Pol LA, van der Flier WM, Korf ESC, Fox NC, Barkhof F, Scheltens P: Baseline predictors of rates of hippocampal atrophy in mild cognitive impairment. Neurology 2007; 69:1491-1497.

-67 de Leeuw FE, Korf E, Barkhof F, Scheltens P: White matter lesions are associated with progression of medial temporal lobe atrophy in Alzheimer disease. Stroke 2006;37:22482252.

68 Meguro K, Sekita Y, Yamaguchi T, Yamada K, Hishinuma T, Matsuzawa T: A study of periventricular hyperintensity. I. Normal brain aging. Arch Gerontol Geriatr 1992;14: 183-191.

-69 Meguro K, Yamaguchi T, Hishinuma T, Miyazawa $\mathrm{H}$, Ono S, Yamada K, Matsuzawa T: Periventricular hyperintensity on magnetic resonance imaging correlated with brain ageing and atrophy. Neuroradiology 1993; 35:125-129.
70 Wiseman RM, Saxby BK, Burton EJ, Barber R, Ford GA, O'Brien JT: Hippocampal atrophy, whole brain volume, and white matter lesions in older hypertensive subjects. Neurology 2004;63:1892-1897.

71 Firbank MJ, Wiseman RM, Burton EJ, Saxby BK, O’Brien JT, Ford GA: Brain atrophy and white matter hyperintensity change in older adults and relationship to blood pressure: brain atrophy, WMH change and blood pressure. J Neurol 2007;254:713-721.

72 Pohjasvaara T, Mantyla R, Salonen O, Aronen HJ, Ylikoski R, Hietanen M, Kaste M, Erkinjuntti T: How complex interactions of ischemic brain infarcts, white matter lesions, and atrophy relate to poststroke dementia. Arch Neurol 2000;57:1295-1300.

73 Grau-Olivares M, Bartres-Faz D, Arboix A, Soliva JC, Rovira M, Targa C, Junque C: Mild cognitive impairment after lacunar infarction: voxel-based morphometry and neuropsychological assessment. Cerebrovasc Dis 2007;23:353-361.

74 Firbank MJ, Burton EJ, Barber R, Stephens S, Kenny RA, Ballard C, Kalaria RN, O’Brien JT: Medial temporal atrophy rather than white matter hyperintensities predict cognitive decline in stroke survivors. Neurobiol Aging 2007;28:1664-1669.

75 Walters RJ, Fox NC, Schott JM, Crum WR, Stevens JM, Rossor MN, Thomas DJ: Transient ischaemic attacks are associated with increased rates of global cerebral atrophy. J Neurol Neurosurg Psychiatry 2003;74:213216.

76 Knoops AJ, van der Graaf Y, Appelman AP, Gerritsen L, Mali WP, Geerlings MI: Visual rating of the hippocampus in non-demented elders: does it measure hippocampal atrophy or other indices of brain atrophy? The SMART-MR study. Hippocampus 2009, Epub ahead of print. DOI 10.1002/hipo.20575.

77 Visser PJ, Verhey FRJ, Hofman PAM, Schel tens P, Jolles J: Medial temporal lobe atrophy predicts Alzheimer's disease in patients with minor cognitive impairment. J Neurol Neurosurg Psychiatry 2002;72:491-497.

78 Revesz T, Hawkins CP, du Boulay EP, Barnard RO, McDonald WI: Pathological find ings correlated with magnetic resonance imaging in subcortical arteriosclerotic encephalopathy (Binswanger's disease). J Neurol Neurosurg Psychiatry 1989;52:1337-1344.

79 von Bohlen und Halbach O, Unsicker K: Morphological alterations in the amygdala and hippocampus of mice during ageing. Eur J Neurosci 2002;16:2434-2440.

80 Waldemar G, Christiansen P, Larsson HB Hogh P, Laursen H, Lassen NA, Paulson OB: White matter magnetic resonance hyperintensities in dementia of the Alzheimer type: morphological and regional cerebral blood flow correlates. J Neurol Neurosurg Psychiatry 1994;57:1458-1465.
81 Pulsinelli WA, Brierley JB, Plum F: Temporal profile of neuronal damage in a model of transient forebrain ischemia. Ann Neurol 1982;11:491-498.

82 Cervos-Navarro J, Diemer NH: Selective vulnerability in brain hypoxia. Crit Rev Neurobiol 1991;6:149-182.

83 Kril JJ, Patel S, Harding AJ, Halliday GM: Patients with vascular dementia due to microvascular pathology have significant hippocampal neuronal loss. J Neurol Neurosurg Psychiatry 2002;72:747-751.

84 Sepulcre J, Goni J, Masdeu JC, Bejarano B, Velez de MN, Toledo JB, Villoslada P: Contribution of white matter lesions to gray matter atrophy in multiple sclerosis: evidence from voxel-based analysis of T1 lesions in the visual pathway. Arch Neurol 2009;66:173179.

-85 Matsusue E, Sugihara S, Fujii S, Kinoshita T, Nakano T, Ohama E, Ogawa T: Cerebral cortical and white matter lesions in amyotrophic lateral sclerosis with dementia: correlation with MR and pathologic examinations. AJNR Am J Neuroradiol 2007;28:15051510.

-86 McMurtray A, Nakamoto B, Shikuma C, Valcour V: Cortical atrophy and white matter hyperintensities in HIV: the Hawaii Aging with HIV Cohort Study. J Stroke Cerebrovasc Dis 2008;17:212-217.

$>87$ Dichgans M: CADASIL: a monogenic condition causing stroke and subcortical vascular dementia. Cerebrovasc Dis 2002;13(suppl 2):37-41

88 Peters N, Holtmannspotter M, Opherk C, Gschwendtner A, Herzog J, Samann P, Dichgans $\mathrm{M}$ : Brain volume changes in CADASIL: a serial MRI study in pure subcortical ischemic vascular disease. Neurology 2006;66: 1517-1522

89 O'Sullivan M, Ngo E, Viswanathan A, Jouvent E, Gschwendtner A, Saemann PG, Duering M, Pachai C, Bousser MG, Chabriat $\mathrm{H}$, Dichgans M: Hippocampal volume is an independent predictor of cognitive performance in CADASIL. Neurobiol Aging 2009; 30:890-897.

90 Liem MK, Lesnik Oberstein SA, Haan J, van der Neut I, Ferrari MD, van Buchem MA, Middelkoop HA, van der Grond J: MRI correlates of cognitive decline in CADASIL: a 7-year follow-up study. Neurology 2009;72: 143-148.

91 Viswanathan A, Godin O, Jouvent E, O'Sullivan M, Gschwendtner A, Peters N, Duering M, Guichard JP, Holtmannspotter M, Dufouil C, Pachai C, Bousser MG, Dichgans $\mathrm{M}$, Chabriat $\mathrm{H}$ : Impact of MRI markers in subcortical vascular dementia: a multi-modal analysis in CADASIL. Neurobiol Aging 2008, E-pub ahead of print. DOI: 10.1016/j.neurobiolaging.2008.09.001. 
-92 van den Heuvel DMJ, ten Dam VH, de Craen AJM, Admiraal-Behloul F, van Es ACGM, Palm WM, Spilt A, Bollen ELEM, Blauw GJ, Launer L, Westendorp RGJ, van Buchem MA, PROSPER Study Group: Measuring longitudinal white matter changes: comparison of a visual rating scale with a volumetric measurement. AJNR Am J Neuroradiol 2006;27:875-878.

$\checkmark 93$ Tiehuis AM, Vincken KL, Mali WP, Kappelle LJ, Anbeek P, Algra A, Biessels GJ: Automated and visual scoring methods of cerebral white matter hyperintensities: relation with age and cognitive function. Cerebrovasc Dis 2008;25:59-66.

$\$ 94$ Gouw AA, van der Flier WM, van Straaten EC, Pantoni L, Bastos-Leite AJ, Inzitari D, Erkinjuntti T, Wahlund LO, Ryberg C, Schmidt R, Fazekas F, Scheltens P, Barkhof F: Reliability and sensitivity of visual scales versus volumetry for evaluating white matter hyperintensity progression. Cerebrovasc Dis 2008;25:247-253.
95 Hachinski V, Iadecola C, Petersen RC, Breteler MM, Nyenhuis DL, Black SE, Powers WJ, DeCarli C, Merino JG, Kalaria RN, Vinters HV, Holtzman DM, Rosenberg GA, Wallin A, Dichgans M, Marler JR, Leblanc GG: National Institute of Neurological Disorders and Stroke-Canadian Stroke Network vascular cognitive impairment harmonization standards. Stroke 2006;37:2220-2241.

96 Basile AM, Pantoni L, Pracucci G, Asplund K, Chabriat H, Erkinjuntti T, Fazekas F, Ferro JM, Hennerici M, O’Brien J, Scheltens $\mathrm{P}$, Visser MC, Wahlund LO, Waldemar G, Wallin A, Inzitari D: Age, hypertension, and lacunar stroke are the major determinants of the severity of age-related white matter changes. The LADIS (Leukoaraiosis and Disability in the Elderly) Study. Cerebrovasc Dis 2006;21:315-322.
97 de Leeuw FE, de Groot JC, Achten E, Oudkerk M, Ramos LM, Heijboer R, Hofman A, Jolles J, van Gijn J, Breteler MM: Prevalence of cerebral white matter lesions in elderly people: a population based magnetic resonance imaging study. The Rotterdam Scan Study. J Neurol Neurosurg Psychiatry 2001; 70:9-14.

-98 Longstreth WT Jr, Bernick C, Manolio TA, Bryan N, Jungreis CA, Price TR, Cardiovascular Health Study Collaborative Research Group: Lacunar infarcts defined by magnetic resonance imaging of 3660 elderly people: the Cardiovascular Health Study. Arch Neurol 1998;55:1217-1225.

99 Hsu YY, Schuff N, Amend DL, Du AT, Norman D, Chui HC, Jagust WJ, Weiner MW: Quantitative magnetic resonance imaging differences between Alzheimer disease with and without subcortical lacunes. Alzheimer Dis Assoc Disord 2002;16:58-64. 